\title{
Evaluation of User Acceptance of Enterprise Resource Planning System at Material Resource Planning Division of PT. Xacti Indonesia
}

\author{
Evaluasi Penerimaan Pengguna Sistem Enterprise Resource Planning PT. Xacti \\ Indonesia
}

\author{
Received: \\ 19 July 2020 \\ Accepted: \\ 28 December 2020 \\ Published: \\ 1 February 2021
}

\author{
${ }^{1 *}$ Fakhri Rahmadan, ${ }^{2}$ Yusi Tyroni Mursityo, \\ ${ }^{3}$ Niken Hendrakusma Wardani \\ ${ }^{1,2}$ Program Studi Sistem Informasi Fakultas Ilmu Komputer \\ Universitas Brawijaya, ${ }^{3}$ Program Studi Agrobisnis Perikanan, \\ Fakultas Perikanan dan Ilmu Kelautan Universitas Brawijaya \\ 1,2,3 Malang, Indonesia \\ E-mail:1fakhrirahmadan@gmail.com,2yusi_tyro@ub.ac.id, \\ niken13@ub.ac.id
}

\begin{abstract}
The purpose of this evaluation is to evaluate user acceptance of the Glovia ERP system, whichever embedded in PC to assist operator staffs to record material stocks. The research methodology used in this study is the UTAUT model adjusted for the research problem's conditions. The issue happens because the Staff feel more comfortable with the old procedure and think it has supported their performance well. The respondents, as the sample in this study, are the staff operator from the MRP division. Data analysis is done using Partial Least Squares - the result of the research state that the Performance Expectancy variable has a significant effect on the Behavioral Intention variable. On the contrary, the other variables do not significantly affect the Behavioral Intention variable. The behavioral Intention variable has an $\mathrm{R}$ square value of 0.352 percent, which states that four independent variables can explain $35.2 \%$ of the Behavioral Intention variable.
\end{abstract}

Keyword-Enterprise Resource Planning, PC tablet, Modified UTAUT

\begin{abstract}
Abstrak-Tujuan dilakukannya evaluasi ini adalah untuk mengetahui apa yang mempengaruhi penerimaan pengguna modul sistem ERP terbaru yang disematkan ke dalam tablet PC untuk melakukan perekaman stok material pada divisi Material Resource Planning. Permasalahan yang muncul dari penggunaan sistem ERP berbasis tablet PC ini dikarenakan masih belum sepenuhnya beradaptasi menggunakan tablet $P C$ dan lebih nyaman menggunakan prosedur lama secara manual berbasis kertas. Populasi pada penelitian ini yaitu para operator staf divisi MRP PT. Xacti Indonesia yang dimandatkan untuk menggunakan sistem ERP berbasis tablet PC. Penelitian ini menggunakan model UTAUT yang dimodifikasi sesuai kondisi permasalahan penelitian. Metode analisis yang digunakan yaitu Partial Least Square dan pengujian untuk pengaruh dari variabel moderator menggunakan Partial Least Square-Multi Group Analysis (PLS-MGA). Hasil pengujian menunjukkan bahwa variabel Performance Expectancy memiliki pengaruh signifikan terhadap variabel Behavioral Intention dan variabel Effort Expectancy, Social Influence, Facilitating Conditions, serta variabel moderator jenis kelamin, umur, dan pengalaman tidak memiliki pengaruh yang signifikan terhadap Behavioral Intention. Variabel Behavioral Intention memiliki nilai $R$ square sebesar 0,352 yang menyatakan keempat variabel mampu menjelaskan persentase variabel Behavioral Intention sebesar 35,2\%.
\end{abstract}

Kata Kunci-Enterprise Resource Planning, Tablet PC, UTAUT Termodifikasi 
INTENSIF, Vol.5 No.1 February 2021

ISSN: 2580-409X (Print) / 2549-6824 (Online)

DOI: https://doi.org/10.29407/intensif.v5i1.14590

\section{INTRODUCTION}

PT. Xacti Indonesia is an Original Equipment Manufacturer (OEM) based company that produces digital products that are then purchased by other companies or retailers using the trademark of the buying company. For now, the product being produced is a digital still camera (Digital Still Camera). At PT. Xacti Indonesia has several divisions to move the company, one of which is the Material Resource Planning (MRP) division. The MRP Division is responsible for managing camera building materials, which will be needed by the production division in manufacturing cameras.

MRP division at PT. Xacti Indonesia categorizes materials for making cameras on shelves, which have been categorized in detail based on the serial number of the material that has been registered since the material came from the vendor received by the Receiving division. MRP division staff operators will take materials according to the production division's requests in producing specific series cameras, then update the stock of goods taken from the ERP system embedded in mobile devices in the form of a compact and portable tablet PC that makes it easier for staff operators to record incoming and outgoing material data on each material shelf in the warehouse a portal application. Before using a tablet PC, the Staff documented the amount of material stock by manually writing it on paper, which at the end of the working day would update the stock on the computer available there.

One of the things that cause companies not to get the benefits and advantages of an ERP system is the reluctance and resistance of users and the company's inability to determine changes in the organizational structure according to the benefits of the technology chosen. [1]. Enterprise Resource Planning (ERP) is a term given to an integrated information system that supports transactions in the form of processed data in managing organizational or company resources that aim to support a company's functions. These resources include funds, people, machines, spare parts, time, materials, and capacity[2]. Enterprise Resource Planning (ERP) consists of a series of integrated software application tools designed to support core business functions [3]. Based on reports at the beginning of implementing the procedure, when the new system was implemented, there were still some employees who had not fully used the tablet PC. It is because there are several obstacles. Therefore they have not fully adapted to using a tablet PC and prefer to use the old manual procedure, which is comfortable and feels that the old procedure has supported their performance well so that it discourages staff operators from using the new procedure. From the problems it was found that the implementation of the portal application embedded in the tablet PC has not been used optimally by staff operators so the focus of this problem lies in the user's intention (Behavioral Intention) to use the latest procedure using the portal application on a tablet 
PC by reviewing it based on the model. that has been determined, namely the modified UTAUT model. With the lack of interest from staff operators in using tablet PC-based applications, information technology investment will not get good feedback considering that the procurement of tablet PC devices and embedded ERP systems is one of the information technology investment projects at PT. Xacti Indonesia.

Based on the results of previous research and the problems that have been collected, a modified UTAUT (Unified Theory of Acceptance and Use of Technology) Model is chosen to adjust the variables to the problem conditions in the field, which can be called Modified UTAUT. The UTAUT model was chosen because based on the problems faced related to the intentions and behavior of staff operators. The variables in the UTAUT indicated according to this problem can be ascertained whether statistically, these variables affect the acceptance of users of the tablet PC-based ERP system PT. Xacti Indonesia. Compared to other models such as the DeLone and McLean success models, which focus more on testing system quality, the HOT Fit (Human Organization Technology) model is oriented towards the alignment of people, organizations, and technology to implement information systems successfully.[4], UTAUT model is considered the right model for this problem. This study also applies three moderating variables, namely, gender, age, experience, and education. As research conducted by He and Lee states that women have a lower experience using computers because and tend to be more anxious about using computers than men[5]. Improving the system implemented can increase. Staff uses the system more to complete their work than pens and paper (Paper-Based)[6]. It is expected that the MRP division of PT. Xacti Indonesia can increase staff operators' willingness to implement a tablet PC-based ERP system in the future.

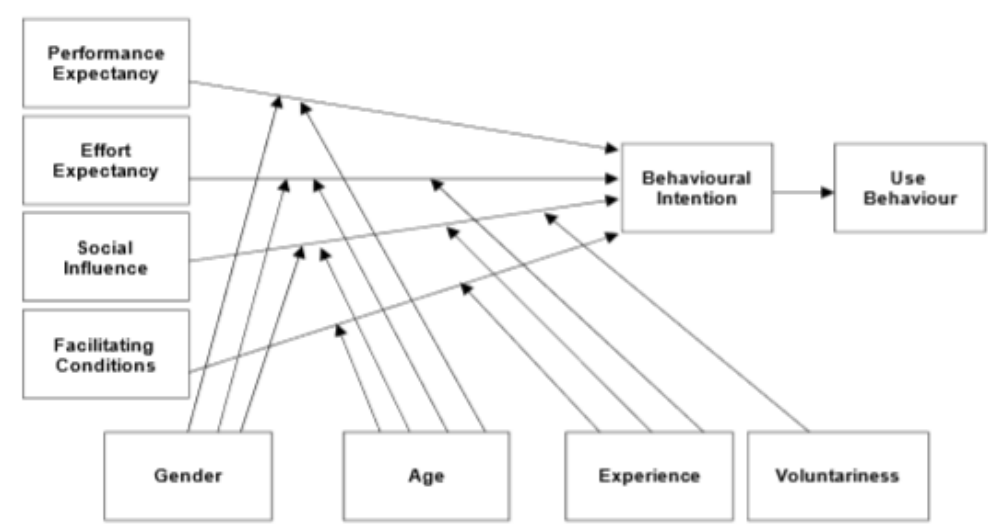

Figure 1. UTAUT MODEL

Unified Theory of Acceptance and Usage of Technology (UTAUT) is a theory related to user acceptance. This theory aims to explain user behavior towards information technology used to examine the effect of variables on behavioral intentions[7]. This model results from a review of a combination of eight acceptance models that have been successfully developed previously [8]. 
INTENSIF, Vol.5 No.1 February 2021

ISSN: 2580-409X (Print) / 2549-6824 (Online)

DOI: https://doi.org/10.29407/intensif.v5i1.14590

Figure 1 shows the UTAUT modeling. It consists of several factors, namely Performance Expectancy (the belief that the extent to which the system will help individuals improve their performance), Effort Expectancy (the level of ease of use of the system), Social Influence (the extent to which an individual feels essential that other people believe he should use a new system), and Facilitating Conditions (individual trust in the presence of the company's infrastructure to be used for system use) which all affect Behavioral Intention which will later affect Use Behavior[8]. The UTAUT model is an instrument for company management to assess the success rate of implementing information technology. Besides, UTAUT can also assist management in understanding the aspects that affect the acceptance and use of information technology[3].

This research refers to research conducted previously as a literature review, including Soliman and friends [9]. They researched the modeling of user intention in using the ERP system of universities in Egypt, research conducted by Wagaw [10], namely the acceptance of locally made ERP systems by companies in Ethiopia. From this research, it can be applied the instruments used, such as statement item models and reliability testing techniques which will be used as references in the evaluation of the mobile-based ERP system of PT. Xacti Indonesia. The results of this study can also be used as a reference for the evaluation results of the mobile-based ERP system of PT. Xacti Indonesia considering the results of this research, can also be applied to developing countries like Ethiopia, research conducted by Lukman Hakim [11]. He evaluated public acceptance of the learning site belajarkoding.net Using UTAUT In the method used by Lukman, namely the PLS testing method and the moderator variables using PLS-MGA, which will be used as a reference for evaluating the mobile-based ERP system of PT. Xacti Indonesia on the set moderator variables.

Research by Andwika[12] analyzes the acceptance of ERP users in manufacturing companies engaged in four-wheeled vehicles in Indonesia, research by Wulandari [13] analyzes the factors that influence user acceptance in using the ERP system at PT. Perkebunan Nusantara XI using a model research model that is modified UTAUT. The results of the analysis conducted by Yulianti and Handayani will be used as a reference regarding the results and discussion of the evaluation of the mobile-based ERP system of PT. Xacti Indonesia and research conducted by Irfan Mahendra[3] analyzed the ERP system acceptance at PT. GBS Uses Unified Theory of Acceptance And Use of Technology (UTAUT). The research conducted by Irfan, the research model, the variables used, and the methods used were used as references in evaluating the mobile-based ERP system of PT. Xacti Indonesia. 


\section{RESEARCH METHOD}

The detailed methodological stages of this research can be seen in Figure 2. Namely, this research begins by identifying the problem formulation, literature studies to find case studies or previous research related to this research. Besides, literature studies are also used to study UTAUT theory and data collection techniques and data analysis techniques using PLS (Partial Least Square). The next is to determine the research method and create a questionnaire by determining the variables. Then the last is to determine the indicators to be determined. Be measured. This indicator will then be translated into statement items[14]. A legibility test is carried out using construct validity using expert judgments and content validity by applying a pilot test. Data analysis is carried out using PLS and PLS. MGA to assess moderator variables. The final part of this research is to draw conclusions and suggestions.

This evaluation uses a saturated sampling method so that the population size is the sample size used for the study. Saturated sampling is a sampling technique when all population members are used as samples[14]. The population used is the staff operator from 3 sections of the MRP division of PT. Xacti Indonesia, namely MRP Big, MRP Small, and Accessory warehouse which are mandated to use a tablet PC-based ERP system for as many as 60 people.

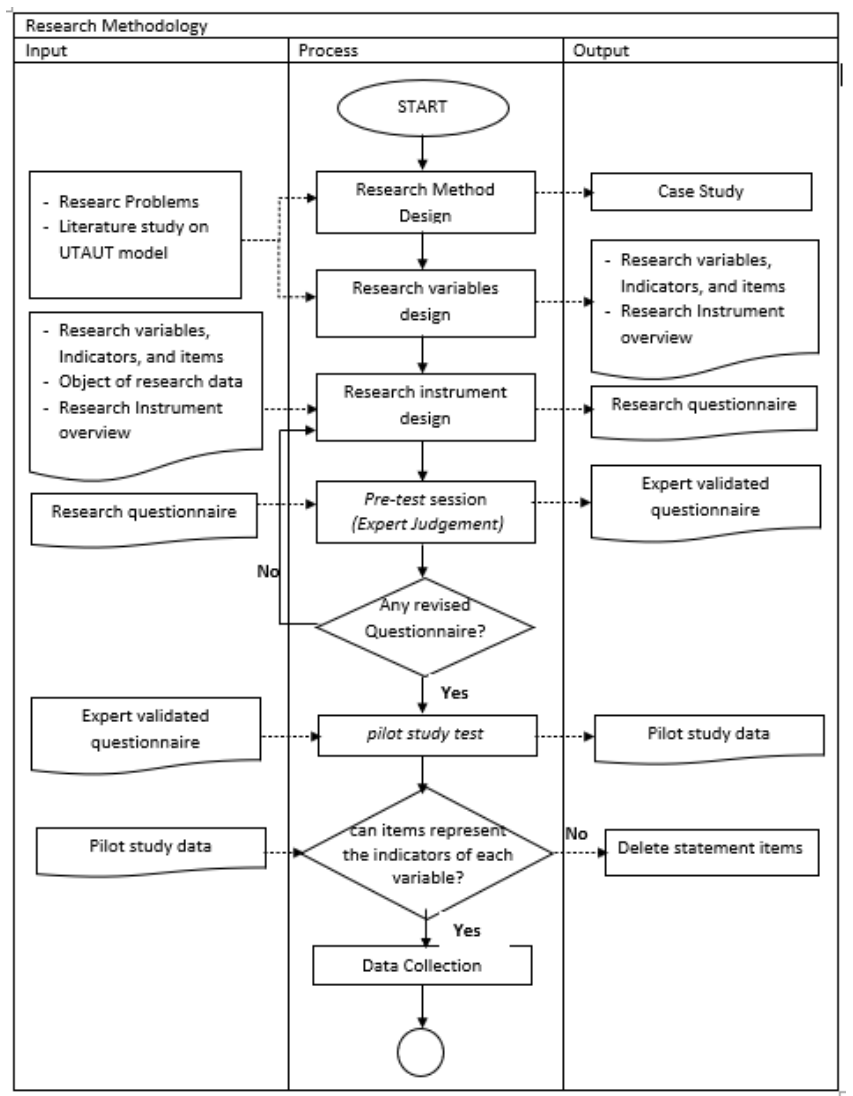

Figure 2. RESEARCH FLOW 
INTENSIF, Vol.5 No.1 February 2021

ISSN: 2580-409X (Print) / 2549-6824 (Online)

DOI: https://doi.org/10.29407/intensif.v5i1.14590

The detailed methodological stages of this research can be seen in Figure 2. Namely, this research begins by identifying the problem formulation, literature studies to find case studies or previous research related to this research. Besides, literature studies are also used to study UTAUT theory and data collection techniques and data analysis techniques using PLS (Partial Least Square). The next is to determine the research method and create a questionnaire by determining the variables. Then the last is to determine the indicators to be determined. Be measured. This indicator will then be translated into statement items[14]. A legibility test is carried out using construct validity using expert judgments and content validity by applying a pilot test. Data analysis is carried out using PLS and PLS. -MGA to assess moderator variables. The final part of this research is to draw conclusions and suggestions.

This evaluation uses a saturated sampling method so that the population size is the sample size used for the study. Saturated sampling is a sampling technique when all population members are used as samples[14]. The population used is the staff operator from 3 sections of the MRP division of PT. Xacti Indonesia, namely MRP Big, MRP Small, and Accessory warehouse which are mandated to use a tablet PC-based ERP system for as many as 60 people.

\section{A. Instrument Design}

The design of research instruments includes variables, indicators, and items. Questionnaire items in the evaluation of tablet PC-based ERP systems use items that refer to previous studies. It also includes related literature adjusted to the study of operational conditions. Then instrument validity and reliability tests are carried out. Source statement items were adopted from some literature, including source statement items adopted from several kinds of literature, including Davis; Moore and Benbasat; Venkatesh; Thompson, Higgins, and Howell; Ajsen and Mahendra are cited in the research of Venkatesh [8] and Williams[15]. Based on table 1, each UTAUT variable used in this study studied the conceptual definition based on the related literature and then adjusted it to the current research conditions, which resulted in an operational definition of each indicator. 
Table 1. RESEARCH VARIABLES AND INDICATORS

\begin{tabular}{|c|c|c|}
\hline Variable & Indicator & Operational Definition \\
\hline \multirow{3}{*}{$\begin{array}{l}\text { Performance } \\
\text { Expectancy }\end{array}$} & $\begin{array}{l}\text { Perceived } \\
\text { Usefulness }\end{array}$ & $\begin{array}{l}\text { the degree to which one believes that } \\
\text { using a tablet PC-based portal } \\
\text { application will improve their work } \\
\text { performance. }\end{array}$ \\
\hline & $\begin{array}{l}\text { Relative } \\
\text { Advantages }\end{array}$ & $\begin{array}{l}\text { The degree to which using a tablet } \\
\text { PC-based portal application is } \\
\text { considered better than using a manual } \\
\text { (paper-based) system. }\end{array}$ \\
\hline & Job-fit & $\begin{array}{l}\text { How is the ability to use a tablet PC- } \\
\text { based portal application to improve } \\
\text { the performance of one's work? }\end{array}$ \\
\hline \multirow{3}{*}{$\begin{array}{l}\text { Effort } \\
\text { Expectancy }\end{array}$} & $\begin{array}{l}\text { Perceived } \\
\text { Ease Of Use }\end{array}$ & $\begin{array}{l}\text { The degree to which one believes that } \\
\text { using a tablet PC based portal } \\
\text { application is more efficient from a } \\
\text { business perspective. }\end{array}$ \\
\hline & Complexity & $\begin{array}{l}\text { The extent to which the tablet PC- } \\
\text { based portal application is used is } \\
\text { deemed challenging and difficult to } \\
\text { understand. }\end{array}$ \\
\hline & Ease of Use & $\begin{array}{l}\text { the extent to which using a tablet PC- } \\
\text { based portal application is considered } \\
\text { problematic in its use }\end{array}$ \\
\hline \multirow[b]{2}{*}{$\begin{array}{l}\text { Social } \\
\text { Influence }\end{array}$} & $\begin{array}{l}\text { Subjective } \\
\text { Norm }\end{array}$ & $\begin{array}{l}\text { One's perception is that most of the } \\
\text { people who matter should use a tablet } \\
\text { PC based portal application }\end{array}$ \\
\hline & Social Factors & $\begin{array}{l}\text { MRP Division staff internalization } \\
\text { process in using the application that } \\
\text { has been provided, which has become } \\
\text { a habit of using tablet PC-based portal } \\
\text { applications. }\end{array}$ \\
\hline \multirow[t]{3}{*}{$\begin{array}{l}\text { Facilitating } \\
\text { Conditions }\end{array}$} & $\begin{array}{l}\text { Perceived } \\
\text { Behavioral } \\
\text { Control }\end{array}$ & $\begin{array}{l}\text { the degree to which understanding is } \\
\text { based on the behavior of the MRP } \\
\text { Division Staff internally and } \\
\text { externally, which includes the realms } \\
\text { of Self Efficacy, Resource Facilitating }\end{array}$ \\
\hline & & $\begin{array}{l}\text { Conditions, and Technology } \\
\text { Facilitating Conditions }\end{array}$ \\
\hline & $\begin{array}{l}\text { Facilitating } \\
\text { Conditions }\end{array}$ & $\begin{array}{l}\text { objective factors in the environment } \\
\text { related to activities that support the } \\
\text { use of tablet PC-based portal } \\
\text { applications. }\end{array}$ \\
\hline $\begin{array}{l}\text { Behavioral } \\
\text { Intention }\end{array}$ & $\begin{array}{l}\text { Behavioral } \\
\text { Intention }\end{array}$ & $\begin{array}{l}\text { someone's interest in behavior that } \\
\text { becomes an intention to carry out that } \\
\text { behavior }\end{array}$ \\
\hline
\end{tabular}

\section{B. Instrument Testing}

The validity test of the instrument is carried out by using the opinion of experts (Expert Judgments). There were revisions to sentences from several questionnaire points, revision of 
INTENSIF, Vol.5 No.1 February 2021

ISSN: 2580-409X (Print) / 2549-6824 (Online)

DOI: https://doi.org/10.29407/intensif.v5i1.14590

negative statements that caused inconsistencies, and adding and improving grammar and words. It can be continued for the pilot study stage, which is a small-scale test by taking a group. The researcher considered to represent the population of this study to test a questionnaire. It has been validated by experts so that it is tested first on the population before taking actual data.[16]. Thirty respondents randomly selected were tested first to test the research instrument that was valid and reliable. The data validity test was conducted to determine the level of data validity and the degree of truth (whether or not an item was valid in the questionnaire given to the respondent) from a data collection process on the research instrument. [13], [17]. The results show that the validity test uses the correlation value of the bivariate Pearson coefficient ( $r$ ) with the $r$ table with the calculated $r$-value that has been processed using SPSS calculations. There is 1 item statement that is invalid because the value of $r$ does not meet the value of the $r$ table, so that the statement is not used and is deleted from the study[12], [13], [17], [18]. To test the reliability using the Cronbach's Alpha technique. The result states that all variables are declared reliable because they have a Cronbach's Alpha value above 0.6.

\section{RESULT AND DISCUSSION}

\section{A. Structural Modeling}

Data analysis using Partial Least Square by conducting several tests using the SmartPLS application tested the moderator variables using PLS-MGA (Partial Least Square-Multi Group Analysis) analysis. The first step to analyze the data with Partial Least Square (PLS) is to describe the structural model in order to know the relationship of each variable along with the indicators that represent it. The structural model consists of the relationship between the four independent variables and one dependent variable, and each indicator is shown in Figure 3. 


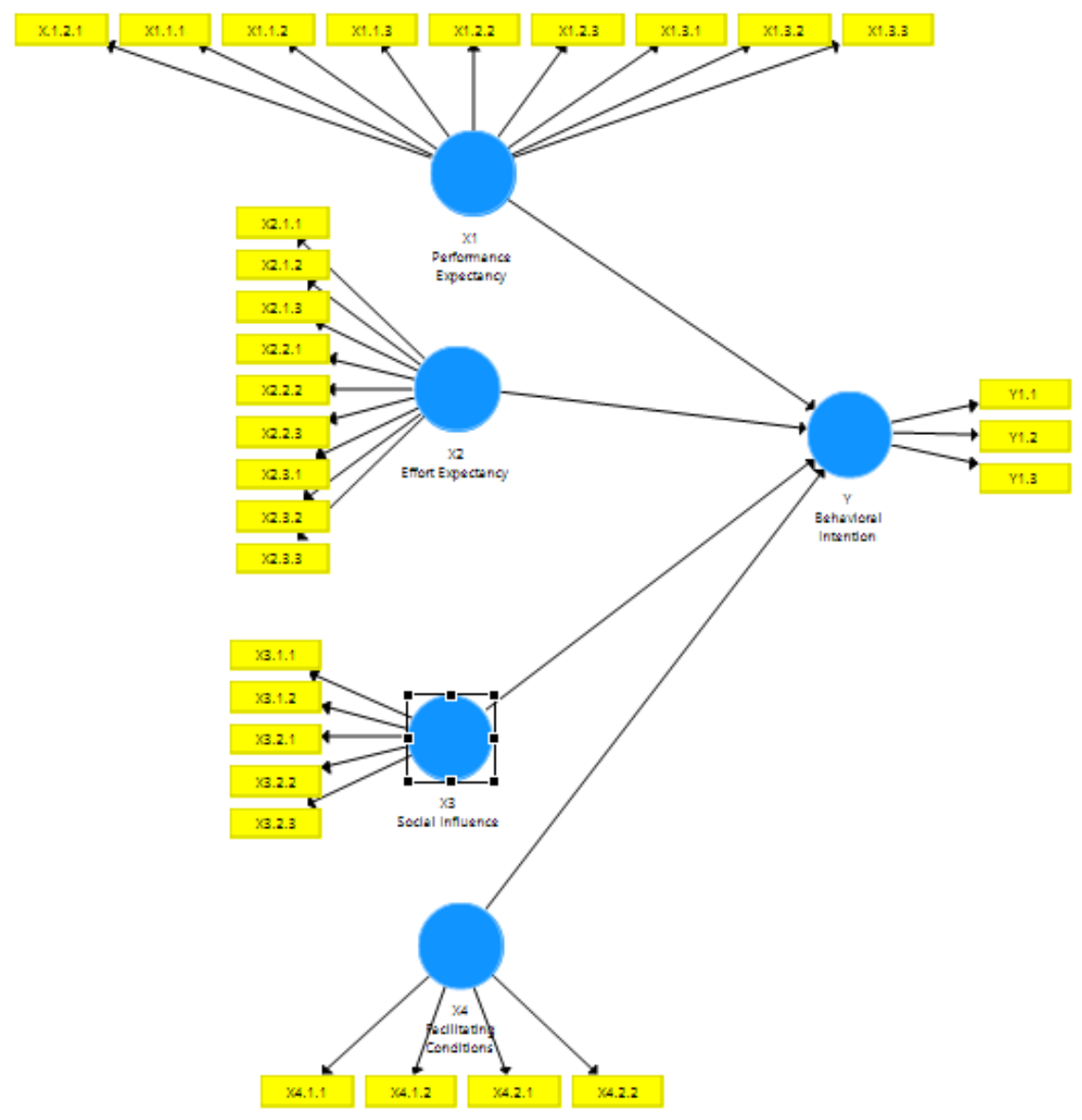

Figure 3. RESEARCH STRUCTURAL MODEL

\section{B. Outer Model Test}

The first stage of testing is the outer model test. This test is conducted to determine the regression value of a reflective latent variable on the indicator that represents it [19]. The convergent validity test calculated the value of the Loading or Outer Loading Factor and the Average Variance Extracted (AVE). For each calculation, it can be said to be valid if for each indicator, the Outer Loading value is $>0.7$ and the AVE value for each variable is $>0,5[19]$. In the discriminant validity test, it is assessed based on the Cross Loading value. For the Cross Loading value, it can be said to meet the requirements of the discriminant validity test if each indicator of the variable has a loading value on the intended variable that is greater than the loading value with other variables.[19]. The results of the validity test as one of the test steps using PLS are presented in table 2. 
Table 2. VALIDITY TEST RESULTS

\begin{tabular}{|c|c|c|c|}
\hline Variable & Item & $\begin{array}{c}\text { Outer } \\
\text { Loading } \\
(>0,7)\end{array}$ & $\begin{array}{c}\text { Average } \\
\text { Variance } \\
\text { Extracted } \\
(>0.5)\end{array}$ \\
\hline \multirow{9}{*}{$\begin{array}{l}\text { Performance Expectancy } \\
\qquad\left(\mathrm{X}_{1}\right)\end{array}$} & $X_{1.1 .1}$ & 0,826 & \multirow{9}{*}{0,680} \\
\hline & $\mathrm{X}_{1.1 .2}$ & 0,769 & \\
\hline & $\mathrm{X}_{1.1 .3}$ & 0,795 & \\
\hline & $\mathrm{X}_{1.2 .1}$ & 0,873 & \\
\hline & $\mathrm{X}_{1.2 .2}$ & 0,809 & \\
\hline & $\mathrm{X}_{1.2 .3}$ & 0,753 & \\
\hline & $\mathrm{X}_{1.3 .1}$ & 0,700 & \\
\hline & $\mathrm{X}_{1.3 .2}$ & 0,746 & \\
\hline & $\mathrm{X}_{1.3 .3}$ & 0,720 & \\
\hline \multirow{8}{*}{ Effort Expectancy $\left(\mathrm{X}_{2}\right)$} & $\mathrm{X}_{2.1 .1}$ & 0,718 & \multirow{8}{*}{0,527} \\
\hline & $\mathrm{X}_{2.1 .2}$ & 0,667 & \\
\hline & $\mathrm{X}_{2.1 .3}$ & 0,806 & \\
\hline & $\mathrm{X}_{2.2 .1}$ & 0,741 & \\
\hline & $\mathrm{X}_{2.2 .2}$ & 0,718 & \\
\hline & $\mathrm{X}_{2.3 .1}$ & 0,644 & \\
\hline & $\mathrm{X}_{2.3 .2}$ & 0,755 & \\
\hline & $\mathrm{X}_{2.3 .3}$ & 0,748 & \\
\hline \multirow{5}{*}{ Social Influence $\left(\mathrm{X}_{3}\right)$} & $\mathrm{X}_{3.1 .1}$ & 0,880 & \multirow{2}{*}{0,675} \\
\hline & $\mathrm{X}_{3.1 .2}$ & 0,737 & \\
\hline & $\mathrm{X}_{3.2 .1}$ & 0,605 & \\
\hline & $\mathrm{X}_{3.2 .2}$ & 0,724 & \\
\hline & $\mathrm{X}_{3.2 .3}$ & 0,736 & \\
\hline \multirow{4}{*}{ Facilitating Conditions $\left(\mathrm{X}_{4}\right)$} & $\mathrm{X}_{4.1 .1}$ & 0,898 & 0,606 \\
\hline & $X_{4.1 .2}$ & 0,747 & \\
\hline & $\mathrm{X}_{4.2 .1}$ & 0,770 & \\
\hline & $\mathrm{X}_{4.2 .2}$ & 0,862 & \\
\hline \multirow{3}{*}{ Behavioral Intention (Y) } & $Y_{1.1 .1}$ & 0.892 & 0,550 \\
\hline & $\mathrm{Y}_{1.1 .2}$ & 0.839 & \\
\hline & $\mathrm{Y}_{1.1 .3}$ & 0.734 & \\
\hline
\end{tabular}

Based on the results of the convergent validity test, which is presented in the test results in table 2 , it is found that the majority of the indicators from the whole have an Outer Loading value $>0.7$. However, there are still four items that have an Outer Loading value $<0.7$. Meanwhile, the overall AVE value has a value greater than 0.5 . It can be concluded from this convergent validity test that the validity of each item is acceptable. However, items that do not meet the convergent validity requirements need to be removed from the research model [12], [13] to avoid problems at a later stage.

For the overall results, reflective indicators have a higher Cross Loading value for their respective variables than the other variables. So it can be concluded that all variables and indicators meet the discriminant validity test. However, there are still four items that are the same 
as the convergent validity test, which has a Cross Loading value below 0.7 so that the two items are removed from the model. [12], [13].

The reliability test was conducted to determine the extent to which the measurement results in this study were reliable. The reliability test is calculated by measuring the Cronbach Alpha value and Composite Reliability. If the test value is above 0.7, then the variable is reliable[20]. Based on the results of the reliability test presented in table 3 using Cronbach's Alpha and composite reliability, it shows that all variables show a number above 0.7 , which states that the condition of the variable is reliable.

Table 3. RELIABILITY TEST RESUlts

\begin{tabular}{cccc}
\hline \hline Variable & $\begin{array}{c}\text { Alpha Cronbach } \\
(>0,7)\end{array}$ & $\begin{array}{c}\text { Composite } \\
\text { Reliability } \\
(>0,7)\end{array}$ & Information \\
\hline $\mathrm{X}_{1}$ & 0,920 & 0,932 & Reliabel \\
\hline $\mathrm{X}_{2}$ & 0,888 & 0,899 & Reliabel \\
\hline $\mathrm{X}_{3}$ & 0,831 & 0,858 & Reliabel \\
\hline $\mathrm{X}_{4}$ & 0,863 & 0,892 & Reliabel \\
\hline $\mathrm{Y}$ & 0,768 & 0,864 & Reliabel \\
\hline
\end{tabular}

C. Inner Model Test

Inner Model testing aims to test the presence or absence of influence between independent variables related to the dependent variable. The structural model can be evaluated using the estimated value of the path coefficients [19] using the p-value or the T-statistic to determine the significance of the structural path meter coefficients. The structural model testing is done by looking at its statistical value. The t-table value for alpha $5 \%$ is 2.004 . So that the parameter is $t$ statistic $>$ t-table [19], [21]. Only the Performance Expectancy variable has a significant effect on the Behavioral Intention variable, and the other independent variables have no significant effect. The results of the structural model evaluation obtained from the SmartPLS Bootstrapping Report are presented in table 4 .

Table 4. PATH COEFFICIENTS RESUlT

\begin{tabular}{ccccc}
\hline & $\begin{array}{c}\text { Original } \\
\text { Sample }\end{array}$ & Sample Mean & $\begin{array}{c}\text { Standard } \\
\text { Deviation }\end{array}$ & T-Statistics \\
\hline $\begin{array}{c}\text { Performance Expectancy (X1) } \\
->\text { Behavioral Intention (Y) }\end{array}$ & 0,606 & 0,564 & 0,136 & 4,467 \\
\hline $\begin{array}{c}\text { Effort Expectancy (X2) -> } \\
\text { Behavioral Intention (Y) }\end{array}$ & $-0,029$ & 0,016 & 0,135 & 0,213 \\
\hline $\begin{array}{c}\text { Social Influence (X3) -> } \\
\text { Behavioral Intention (Y) }\end{array}$ & $-0,213$ & $-0,222$ & 0,163 & 1,309 \\
\hline $\begin{array}{c}\text { Facilitating Conditions (X4) - } \\
>\text { Behavioral Intention (Y) }\end{array}$ & $-0,157$ & $-0,124$ & 0,166 & 0,946 \\
\hline
\end{tabular}


INTENSIF, Vol.5 No.1 February 2021

ISSN: 2580-409X (Print) / 2549-6824 (Online)

DOI: https://doi.org/10.29407/intensif.v5i1.14590

\section{Test of Moderator Variables}

For the evaluation of structural models influenced by gender moderator variables, the PLSMGA (Partial Least Square-Multigroup Analysis) method is carried out. It examines whether there is an influence or intervention from the moderator variable on the independent variable's relationship with the dependent variable, a feature found in the application. SmartPLS 3.Significant results are indicated at an alpha of $5 \%$ of the error rate if the p-value is less than 0.05 or greater than 0.95 for specific differences from group-specific path coefficients.[22], [23]. Moderator variables can be interpreted by dividing the overall data into two sub-sample groups. By finding the cut-off point or mean value in a sample, the sample can be divided into two groups[11]. Table 5 shows the PLS-MGA results on the gender moderator variable obtained from the PLS-MGA Report using SmartPLS. The results state that the overall moderator variables, namely gender, age, and experience tested, do not interfere with any relationship between the independent variable and the dependent variable.

Table 5. PLS-MGA RESULT

\begin{tabular}{|c|c|c|c|}
\hline \multicolumn{4}{|c|}{ Gender Moderator Variable } \\
\hline & $\begin{array}{c}\text { Path Coefficient-diff (Male- } \\
\text { Female) }\end{array}$ & P-Values & Information \\
\hline $\mathrm{X}_{1->}>\mathrm{Y}$ & 0.373 & 0.867 & There is no influence \\
\hline $\mathrm{X}_{2->}-\mathrm{Y}$ & 0.177 & 0.382 & There is no influence \\
\hline $\mathrm{X}_{3}->\mathrm{Y}$ & 0.100 & 0.330 & There is no influence \\
\hline $\mathrm{X}_{4->}>\mathrm{Y}$ & 0.341 & 0.143 & There is no influence \\
\hline \multicolumn{4}{|c|}{ Age Moderator Variables } \\
\hline & $\begin{array}{l}\text { Path Coefficient-diff }(\leq 27 \\
\text { years old }-\geq 28 \text { years old })\end{array}$ & P-Values & Information \\
\hline $\mathrm{X}_{1->}>\mathrm{Y}$ & 0.170 & 0.697 & There is no influence \\
\hline $\mathrm{X}_{2->Y}$ & 0.340 & 0.818 & There is no influence \\
\hline $\mathrm{X}_{3}->\mathrm{Y}$ & 0.200 & 0.667 & There is no influence \\
\hline $\mathrm{X}_{4}->\mathrm{Y}$ & 0.001 & 0.482 & There is no influence \\
\hline \multicolumn{4}{|c|}{ Experience Moderator Variables } \\
\hline & $\begin{array}{r}\text { Path Coefficient-diff } \\
\text { ( } \leq 3 \text { years }-\geq 4 \text { years) }\end{array}$ & P-Values & Information \\
\hline $\mathrm{X}_{1->}>\mathrm{Y}$ & 0.295 & 0.746 & There is no influence \\
\hline $\mathrm{X}_{2}->\mathrm{Y}$ & 0.317 & 0.774 & There is no influence \\
\hline $\mathrm{X}_{3}->\mathrm{Y}$ & 0.248 & 0.769 & There is no influence \\
\hline $\mathrm{X}_{4->}>\mathrm{Y}$ & 0.592 & 0.062 & There is no influence \\
\hline
\end{tabular}

E. Discussion of Hypotheses

To test the hypothesis, whether it is accepted or not, it is done by looking at the statistical value. The t-table value for alpha $5 \%$, and the amount of data of 60 is 2.004 . So that the parameter is t-statistic $>\mathrm{t}$-table for $\mathrm{Ha}$ accepted $\mathrm{HO}$ is rejected[13], [21], [23]. Based on $\mathrm{t}-$ statistical testing results, the hypothesis testing model can be described, as shown in Figure 4. 


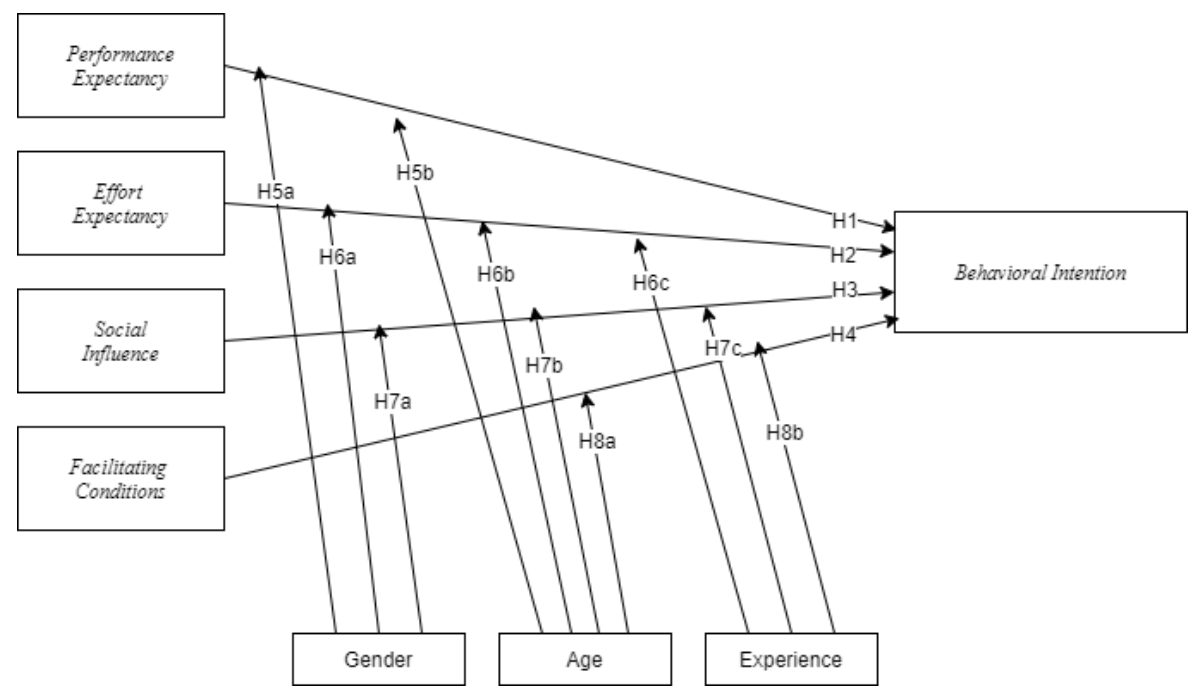

Figure 4. RESEARCH HYPOTHESIS MODEL

Based on the results of testing the first hypothesis, it shows that Performance Expectancy will affect Behavioral Intention in using a tablet PC-based ERP system. It is based on the original sample value of 0.606 , which means that it leads to a positive relationship and a t-statistic value more significant than the t-table value of 4.467. The first hypothesis is accepted.

The results of testing the second hypothesis are Effort Expectancy affects Behavioral Intention in the use of a tablet PC-based ERP system. The calculation results show that the Original Sample value leads to a negative value of -0.029 . The t-statistic generated by the relationship between the two variables is 0.213 , which indicates a relationship. The two variables do not have a significant effect, so that they have an impact on testing the hypothesis, namely, the decision is rejected.

Based on the results of testing the third hypothesis, it shows that Social Influence will affect Behavioral Intention in using a tablet PC-based ERP system. Itis based on the original sample value of -0.213 , which means that it leads to a negative relationship and a t-statistic value lower than the t-table value. 1,309 . So that the third hypothesis is rejected.

The results of testing the fourth hypothesis indicate that Facilitating Conditions do not affect Behavioral Intention in using a tablet PC-based ERP system. The calculation results show that the Original Sample value leads to a negative value of -0.157 . The $t$-statistic generated by the relationship between the two variables is 0.946 , so that it has an impact on hypothesis testing. Namely, the decision is rejected.

The results of testing the moderator variables using PLS-MGA show that the three moderating variables moderate the four certain independent variables according to the model, indicate that there is no significant effect of moderation effect on the relationship between variables. It impacts hypothesis testing so that hypotheses five, six, seven, and eight are rejected. 
INTENSIF, Vol.5 No.1 February 2021

ISSN: 2580-409X (Print) / 2549-6824 (Online)

DOI: https://doi.org/10.29407/intensif.v5i1.14590

The results of the test show that only the Performance Expectancy variable is proven to affect behavioral intention (intention to use). Hence, it is seen that the perception of staff operators regarding the usefulness of using the Glovia portal application for work, accelerating work, and increasing productivity and performance affect the intentions of division staff operators. MRP to use the tablet PC-based Glovia portal application.

\section{F. Recommendation}

Based on the test results, the effect of Performance Expectancy on Behavioral Intention is proven to significantly affect Behavioral Intention in the use of tablet PC-based ERP systems at PT. Xacti Indonesia. It is necessary to conduct regular socialization to increase their work productivity and interest. They will experience more benefits and improve performance when using the Glovia portal application compared to updating stock material manually using a pen. and paper. According to Marler, Dulebohn, and Liang, who was cited in Asa's research[17] stated that the training carried out by an organization when implementing a new system fulfills at least two important objectives, namely that the organization must facilitate learning how to use the system to be implemented to users. Staff operators must know how to use the Glovia portal application according to the features presented by the application so that the results of the work they produce are better with the work they produce when using the previous system. Second, the training conducted for users must form a positive attitude towards the system to be implemented

\section{CONCLUSION}

In the Performance Expectancy variable, the researcher concludes that based on the study results, there is a significant influence on the Behavioral intention variable in using the tablet PCbased Glovia application used by the Operators Staff of the MRP division of PT. Xacti Indonesia. It indicates that the Staff Operators feel that the glovia application is influential. Especially in improving their performance in recording material stocks using a mobile-based ERP system using a tablet PC compared to using the previous procedure manually using paper material for stock list templates and pens. Moreover, their productivity is also increased more than the previous procedure, which makes the execution of their work can be completed more effectively and efficiently. Whereas in the research results, the variable Effort Expectancy, Social Influence, and Facilitating Conditions on Behavioral Intention shows no significant effect. Based on the results of the effect of the moderator variable from each of the variables tested in this study, it shows that there is no significant effect. So this shows that the intervention of each moderator variable does not have a significant effect and difference between the two groups of each 
moderator variable. Suggestions that can be given are expected in future studies to examine other variables that influence the Behavioral Intention variable so that the research results obtained will be better. Although the characteristics of dynamic users are because 50 percent of the population are contract employees (outsourcing), it is hoped that this research can be used as a reference for further evaluation research.

\section{REFERENCES}

[1] P. P. Dewi and N. L. P. Asriani, "Analisis Faktor-Faktor Kesuksesan Penerapan Enterprise Resource Planning (ERP) Pada Perusahaan Pengguna ERP Wilayah Bali," J. Ris. Akunt. Mercu Buana, vol. 5, no. 1, p. 39, 2019.

[2] T. Asgar, "Towards Better Engineering of Enterprise Resource Planning Systems," no. May 2017, 2016.

[3] I. Mahendra, "Analisa Penerimaan Sistem Enterprize Resource Planning ( ERP ) Pada PT GBS Megguakan Unified Theory Of Acceptance And Use Of Technology ( UTAUT )," vol. XII, no. 2, pp. 190-200, 2016.

[4] I. P. Ramayasa, "Evaluation Model of Success and Acceptance of E-Learning," J. Theor. Appl. Inf. Technol., vol. 3182, no. 3, pp. 462-469, 2015.

[5] N. Achim and A. Al Kassim, "Computer Usage: The Impact of Computer Anxiety and Computer Self-efficacy,” Procedia - Soc. Behav. Sci., vol. 172, pp. 701-708, 2015.

[6] B. Aldosari, S. Al-Mansour, H. Aldosari, and A. Alanazi, "Assessment of factors influencing nurses acceptance of electronic medical record in a Saudi Arabia hospital," Informatics Med. Unlocked, vol. 10, no. December 2017, pp. 82-88, 2018.

[7] Hariyadi and R. Rival, "Penerapan Teknologi Informasi Digital Library Ur Dengan Menggunakan Technology Acceptance Model Di Fisip Universitas Riau," Jom Fisip, vol. 4, no. 2, pp. 1-17, 2017.

[8] V. Venkatesh, Mi. G. Morris, G. B. Davis, and F. D. Davis, "USER ACCEPTANCE OF INFORMATION TECHNOLOGY: TOWARD A UNIFIED VIEW,” MIS Q. Manag. Inf. Syst., vol. 27, pp. 425-478, 2003.

[9] M. S. M. Soliman, N. Karia, S. Moeinzadeh, M. S. Islam, and I. Mahmud, "Modelling intention to use ERP systems among higher education institutions in Egypt: UTAUT perspective,” Int. J. Supply Chain Manag., vol. 8, no. 2, pp. 429-440, 2019.

[10] M. Wagaw, "Acceptance of homegrown enterprise resource planning (ERP) systems in Ethiopia," Appl. Informatics, vol. 4, no. 1, p. 6, 2017.

[11] L. Hakim, "Evaluasi Terhadap Penerimaan Masyarakat Terhadap Situs Pembelajaran belajarkoding.net Menggunakan UTAUT," Universitas Airlangga, 2018.

[12] V. R. Andwika and R. W. Witjaksono, "Analysis of User Acceptance of ERP System on After Sales Function Using Unified Theory of Acceptance and Use of Technology (UTAUT) Model,” Int. J. Adv. Data Inf. Syst., vol. 1, no. 1, pp. 26-33, 2020.

[13] P. Wulandari, N. H. Wardani, and M. C. Saputra, "Evaluasi Terhadap Penerimaan Pengguna Sistem Enterprises Resource Planning PT . Perkebunan Nusantara XI ( Persero ) Dengan Model Adapted," J. Pengemb. Teknol. Inf. dan Ilmu Komput. Univ. Brawijaya, vol. 2, no. 9, pp., 2841-2849, 2018.

[14] Sugiyono, Metode Penelitian : Kuantitatif, Kualitatif, dan R\&D. 2017.

[15] M. D. Williams, N. P. Rana, and Y. K. Dwivedi, The unified theory of acceptance and use of technology (UTAUT): A literature review, vol. 28, no. 3. 2015.

[16] N. K. Lowe, "What Is a Pilot Study?," JOGNN - J. Obstet. Gynecol. Neonatal Nurs., vol. 48, no. 2, pp. 117-118, 2019.

[17] A. Arifudin, Y. T. Mursityo, and A. D. Herlambang, "Evaluasi Kualitas Sistem Informasi Perencanaan dan Penganggaran Badan Perencanaan, Penelitian, 
INTENSIF, Vol.5 No.1 February 2021

ISSN: 2580-409X (Print) / 2549-6824 (Online)

DOI: https://doi.org/10.29407/intensif.v5i1.14590

Pengembangan Kota Malang Dengan Technology Acceptance Model (TAM) Termodifikasi,” J. Pengemb. Teknol. Inf. dan Ilmu Komput., vol. 3, no. 6, pp., 59175925, 2019.

[18] A. Kusumahati, "ANALISIS CUSTOMER PERCEIVED VALUE PRODUK SWEETENER TROPICANA SLIM MELALUI PROGRAM CUSTOMER EDUCATION," Univ. Pendidik. Indonesia. Repos., pp. 1-9, 2015.

[19] J. Sarwono and U. Narimawati, Membuat Skripsi, Tesis, dan Disertasi dengan Partial Least Square SEM (PLS-SEM), 1st ed. Yogyakarta: C.V ANDI OFFSET, 2015.

[20] M. Al-Emran, V. Mezhuyev, and A. Kamaludin, PLS-SEM in Information Systems Research: A Comprehensive Methodological Reference, vol. 845. Springer International Publishing, 2019.

[21] A. S. Hussein, "Penelitian Bisnis dan Manajemen Menggunakan PLS (smart-PLS 3.0)," 2015.

[22] SmartPLS, "Partial Least Square - Multigroup Analysis (PLS-MGA)." [Online]. Available: $\quad$ https://www.smartpls.com/documentation/algorithms-andtechniques/multigroup-analysis. [Accessed: 20-Mar-2020].

[23] A. Afthanorhan, A. Aimran, and S. Ahmad, "Permutation Test, Non-parametric, and Confidence Set Approaches to Multi-Group Analysis for Comparing 2 Groups Using Partial Least Square Structural Equation Modeling (Pls-Sem)," Adv. Res., vol. 4, no. 5, pp. 315-328, 2015. 